\title{
КИТАЙСКИЙ СЕВЕРНЫЙ ТЕАТР ВО ВЛАДИВОСТОКЕ (ПО МАТЕРИАЛАМ АРХИВНЫХ ДОКУМЕНТОВ) ${ }^{1}$
}

\section{CHINESE NORTH THEATER IN VLADIVOSTOK (ACCORDING TO ARCHIVAL DOCUMENTS)}

Zhao Huiqing

Meng Fanhong

S. Dudarenok

Summary: The article examines the history of the development of the Chinese theater in Vladivostok in the 1920s-1930s. It is noted that the creators of the theaters attempted to combine Chinese theatrical traditions, reflecting the national identity of the Chinese people, and new realities that presuppose the development of proletarian art in a young socialist state. The creative path of the Chinese Theater of Working Youth, which in 1831-1938 was directed by N.Z. Kiryuchenko, analyzed in more detail.

Keywords: theater, China, migration, Far East, Vladivostok, Northern theater, Chinese Theater of Working Youth.
Чжао Хуэйцин

Доцент, Хэйхэский университет (Хэйхэ, КНР); аспирант, Дальневосточный федеральный университет

(Владивосток)

273004890@q9.com

Мэн Фаньхун

Профрессор, Хэйхэский университет (Хэйхэ, КНР) 479884839@q9.com

Дударенок Светлана Михайловна

Д.и.н., профессор, в.н.с., Институт истории, археологии и этнографии народов Дальнего Востока ДВО РАН

(Владивосток) dudarenoksv@gmail.com

Аннотация: В статье рассматривается история развития китайского театра во Владивостоке в 1920-1930-х гг. Отмечается, что создателями театров предпринимались попытки соединить китайские театральные традиции, отражавшие национальную самобытность китайского народа, и новые реалии, предполагающие развитие пролетарского искусства в молодом социалистическом государстве. Более подробно анализируется творческий путь китайского Театра рабочей молодёжи, которым в 1831-1938 гг. руководил Н.З. Кирюченко.

Ключевые слова: театр, Китай, миграция, Дальний Восток, Владивосток, Северный театр, китайский Театр рабочей молодёжи.

Дальнем Востоке пекинская музыкальная драма (цзинцзюй), представляла собой одну из пяти видов китайских традиционных опер и наиболее полно выражала дух и характер традиционного театрального искусства [8, с. 116]. По содержанию китайские пьесы делились на три группы: историческая драма, в основе которой лежали реальные исторические события; пьесы на бытовые темы, основанные на историях из обыденной жизни и пьесы фантастически-мифологического содержания $[11$, c. 5]. Драма разделялась на военную (у-си) и гражданскую (вень-си). В пьесах отражалась общественная и религиозная жизнь китайцев, их отношение к добру, злу, справедливости, прославлялись военные подвиги.

Китайская театроведческая традиция рассматривает театр как синтез четырех равноправных элементов: пение (чан), декламация (нянь), движения и танец (цзо), борьба и акробатика (да). Все актеры должны были владеть этими элементами, являющимися основой «актер-

Самая распространённая и в Китае, и на русском

Исследование выполнено в рамках научно-исследовательского проекта в области философии и социальных наук провинции Хэйлунцзян «Культурно-просветительская работа среди китайцев на Дальнем Востоке России 1920- 1930-е годы», № 19SSB052 (2019); проекта экономического и социального развития в провинции Хэйлунцзян «Образ Китая в русской литературе и документах Дальнего Востока 1900-2000 гг.», № 20531 (2020) и Совета по стипендиям КНР (2019-2020). 
ского мастерства», которому будущие актеры обучались с малых лет, считая, что только с их помощью можно в полной мере раскрыть художественные особенности пекинской оперы и лучше представить различные образы персонажей.

Зрительный зал китайского театра походил на клуб, за несколько часов до начала спектакля он уже был полон. Сюда приходили отдохнуть, провести время со своими друзьями и посмотреть игру актеров. В стоимость билета входило пребывание в театре с 19:00 до 23:0024:00 часов, просмотр пьес и гимнастических номеров, а также чай и полотенце для вытирания пота. За отдельную плату зрителям предлагали семечки (шелуху сплевывали прямо на пол), пиво, лимонад [8, с. 118].

В.В. Граве отмечал, что китайские театры имелись во всех населенных пунктах Дальнего Востока, в которых проживало значительное китайское население. Представления, как правило, устраивались в условиях открытого пространства, действовали и временные театры, которые были особенно активны в период китайских новогодних праздников [4, с. 119].

Дальневосточные китайские театры играли важную роль в существовании китайской диаспоры. Для большого количества неграмотных китайцев именно театральные представления были основным зрелищным мероприятием и источником сведений о прошлом Китая и об устройстве мира.

По архивным документам и историческим публикациям установлено, что с момента открытия первого театра в 1898 г. и до закрытия последнего, владельцами или арендаторами китайских театров, во Владивостоке были Чэн Шанли, Ван Тынсин, Хоу Фучан, Ду Киюн, Сун Янчун, Тифонтай, Юнхозан, Мария Купер [2, с. 185].

В театрах, существовавших официально, не только устраивались представления, но и читали лекции. Нередко на китайских собраниях выступали ораторы с речами политического содержания. Здесь же прибывшими из Китая официальными лицами проводились разного рода патриотические компании, почти не контролировавшийся русскими властями и полицией [9, с. 84].

В 1920-1930 годы на Дальнем Востоке работало шесть китайских театров: два во Владивостоке, по одному - в Хабаровске, Благовещенске, Никольск-Уссурийске и Спасске.

Театр вместе с опиекурением и банковками были любимые развлечения китайцев. Их представления всегда привлекали многочисленную публику. Хотя постановки не выдерживали никакой критики (чаще всего это были пьесы фантастическо-легендарно-исторического поряд- ка $[25$, л. 30], китайцы на театр часто тратили все накопленные деньги.

Одним из крупных и прибыльных китайских театров был китайский театр в г. Никольск-Уссурийске, принадлежащий богатому и известному предпринимателю Пан Хозину $[18$, л. 17]. Во Владивостоке существовало два китайских театра: Северный — «Сун-чжеу-утай» («Никогда не стареющий, как молодой бамбук») и Южный — «Юнсян-ча-шан» («Благостно вечный дух чаепития»). В Южный театр ходили в основном состоятельные китайцы, а в Северный - китайские рабочие и крестьяне [1, с. 221]. Между театрами шла острая конкурентная борьба.

В 1928 г. Южный театр был закрыт под предлогом нарушения требований санитарной и пожарной инспекции, а на его площадях было решено организовать китайский кинотеатр [3, с. 94]; Северный театр - реформировался и расширил свою деятельность: был организован красный уголок, ликпункт, создан местком: августу 1928 г. около 90\% артистов театра были членами профсоюза. Театр стал называться «Красная волна» $[16, л$. 19], его директором был назначен член ВКП(б) Н.3. Кирюченко (китайское имя - Е-Чун-Сен), режиссёром - Цай Ен. (Кирюченко работал в китайском театре с 1923 г. утверждал, что является членом КПК, однако никаких партийных документов на руках не имел [23, л. 7]). Осенью 1930 г. по решению Далькрайкома было создано управление китайскими театрами на Дальнем Востоке, и Н.3. Кирюченко стал совмещать должности директора китайского театра во Владивостоке, управления китайскими театрами в Дальневосточном крае, а с марта 1931 г. и директора китайского Театра рабочей молодежи (ТРАМа).

Вопрос о состоянии работы китайских театров неоднократно рассматривался на заседаниях Китсовещаний. Так, например, на совещании 28 марта 1928 г. обсуждали существующие в деятельности китайских театров недостатки: «а) полное отсутствие партийного руководства в работе театра; б) наличие ряда случаев злоупотреблений со стороны уполномоченного и председателя месткома коллектива китайских артистов, а также наличие у них на крупную сумму контрабандных товаров; в) идеологическая невыдержанность, проводимых в театре постановок; г) отсутствие в работе месткома всякой коллегиальности, заменяемой безраздельной диктатурой его председателя - Ли-Куена (опиокурильщик); д) отсутствие всякой отчетности о движении сумм по театру и практики заслушивания отчетов о работе коллектива театра на Правлении объединенных коллективов при «Бирже труда», вследствие чего возможны злоупотребления в финансовой сфере» $[26$, л. 5]. Поэтому отделу народного образования рекомендовали «...обратить особое внимание на деятельность китайских театров...» $[18$, л. 202]. 
Осенью 1929 г. китайский театр «Красная волна» передали краевому управлению театрально-зрелищными предприятиями (УТЗП). УТЗП, по словам управляющего китайскими театрами Дальнего Востока Н.3. Кирюченко, «не уделяло должного внимания владивостокскому китайскому театру», не понимало «какое громадное значение имеет китайский театр как культурный центр национальных меньшинств на Дальнем Востоке», что УТЗП рассматривает «театр лишь как источник доходов, используя доходы китайского театра для покрытия дефицита в своем бюджете» $[27$, л. 1$]$.

В феврале 1931 г. в докладной записке «Из истории китайских театров на Дальнем Востоке» [27, л. 1-4] Н.3. Кирюченко приводит следующие данные: в течение 1929/1930 года УТЗП заняло у театра 14 тыс. руб. Из этой суммы возвратило только 7 тыс. 500 руб., а остальные потратили на покрытие дефицита Музыкальной комедии (1000 руб.), городского театра (3000 руб.); в июле 1930 г. был произведен новых заем в размере 10 тыс. руб. на возврат Госбанку аванса на покрытие убытков после пожара, УТЗП возвратило китайскому театру только 7 тыс. 500 руб.

Из-за отсутствия достаточных средств положение китайского театра было тяжелым, зданию театра требовался капитальный ремонт. Санитарные условия не отвечал самым элементарным требованиям: «температура в театре зимой не превышала 5-6 градусов» (зимой 1930 г. из-за недостатка угля и плохих печей театр не работал несколько дней); «из-за холода в театре бывает много пустых мест»: летом артистам «работать бывает совершенно невозможно из-за самых примитивных уборных, расположенных возле кулис» - все это вызывало недовольство со стороны артистов [27, л. 1].

Артисты были недовольны не только отвратительными условиями труда, но и неполучением «известного процента зарплаты в валюте», в связи с чем «некоторые артисты (большинство самых лучших) из старого китайского театра возвратились обратно в Китай», в результате театр оказался в трудном положении: чтобы подготовить новые кадры артистов нужно было время, а заменить их «старыми артистами» было невозможно из-за «полного отсутствия валюты...» $[27$, л. 3].

Работающие в театре на тот момент «старые кадры», происходили «из мелкобуржуазной, но бедной среды», они получили «свое артистическое образование при старом режиме в Китае», и поэтому обычно носили «отпечаток этой среды»: большинство артистов курили опиум, играли в азартные игры и «имели привычки старой китайской буржуазии». Кроме этого репертуар театра оставался старым, «ничего не имеющим общего с культурной революцией» [27, л. 2].
Для того чтобы решить материальные проблемы, коллектив театра в 1931 г. попросил у УТЗП ежегодную субсидию в 60 тыс. руб. «на предмет организации нового китайского театра», но денег не получил и вынужден был покрывать расходы из собственных средств [27, л. 3].

В докладной записке «Из истории китайских театров на Дальнем Востоке» [27, л. 1-4] Н.3. Кирюченко обращал внимание органов власти на проблему подготовки кадров для нового китайского театра. Для решения этой задачи необходимо, по его мнению, «организовать студию китайского театра», в которую пригласить «из школ, рабочих университетов и др. учебных заведений Дальнего Востока молодых китайских товарищей, рабочих, но получивших уже некоторое политическое и культурное образование», предпочтение при отборе отдавать тем «кто уже знаком с артистической жизнью, которые участвуют в драмкружках и т.д.» [27, л. 2-3]. В данную студию предполагалось принять 30 студийцев (10 женщин и 20 мужчин). Кроме артистической подготовки студийцам предполагалось дать и общеполитическую подготовку. По плану первое время студия должна была давать постановки в театре 2-3 вечера в неделю, причем постановки производить не только во Владивостоке, но и в других городах.

Высказал свои соображения Н.3. Кирюченко и в отношении репертуара театра. Он подчеркнул, что полностью заменить репертуар театра невозможно, что необходимо сохранить его национальную форму (смесь оперы и оперетты) и в то же время совершенно изменить содержание. Эти изменения, по его мнению, можно произвести тремя путями: а) пересмотреть и изменить некоторые из идущих пьес, оставив их как иллюстрацию жизни буржуазии и феодалов в Китае, после постановки устраивать обсуждение данных пьес, во время которого стараться разъяснить зрителю какую цель театр преследовал, ставя эти вещи; б) создать, написать новые пьесы, показывающие классовую борьбу в Китае, эксплуатацию трудящихся масс помещиками, компрадорами и империалистами, показывать в этих произведениях эпизоды из революционной борьбы китайского пролетариата за свое освобождение (восстание тайпинов, революция 1925-1927 годов и т.д.); в) перевести на китайский язык и поставить некоторые вещи из советского репертуара (например, «Рычи Китай» и т.д.). Трудности в замене старого репертуара новым заключались ещё и в том, что новые молодые кадры артистов «еще недостаточно подготовлены», а «культурный уровень китайских трудящихся масс недостаточно развит» [27, л. 2].

Несмотря на выявленные недостатки, китайские театры считались важнейшими учреждениями для агитационно-пропагандистской работы. Например, на заседании бюро Владивостокского Горкоме ВКП(б) от 25 января 1931 г. предлагалось в китайских театрах перед началом 
спектаклей проводить антирелигиозные доклады [14, л. 70]. По мнению партийных и советских органов, это может повысить эффективность политико-воспитательной работы, так как театры представляют собой учреждения, которые массово посещают китайские рабочие.

В 1931 г. Далькрайком ВКП(б) выступил с инициативой создания китайского театра рабочей молодежи (китайского ТРАМа), альтернативного традиционному китайскому театру [5, с. 58].

Необходимость открытия нового театра Н.3. Кирюченко объяснял тем, что на Дальнем Востоке проживало около 60 тыс. китайских рабочих, но на это количество китайцев имелась «всего одна художественная единица - китайский театр во Владивостоке», который представлял собой «старый феодальный театр ... застывшей в своих канонах», показывающий «в своих пьесах войны между феодалами и если бытовые темы - то публичные дома, с героями, где симпатия зрителя невольно на стороне феодала-купца, ростовщика» $[19$, л. 1]. По его мнению, «такая чуждо классовая к современной действительности и вопросам волнующими каждого китайского рабочего - работа театра — не могла удовлетворить китайского рабочего» $[19$, л. 1].

Основная задача нового театрального коллектива первоначально состояла в отходе от форм и содержания традиционных китайских постановок, поэтому развернулся процесс его откровенной русификации. С этой целью был приглашен русский режиссер, началась работа над пьесой «Красные языки», переведенной на китайский язык. Однако новый русифицированный спектакль оказался совершенно непонятным китайской публике, пришлось вернуться к ранее отвергнутому стилю национального китайского театра, изучить его особенности, чтобы найти общий язык с китайским зрителем. Для этого с большим трудом руководству ТРАМа удалось уговорить актеров старого китайского театра организовать обучение начинающих актеров, тем не менее, договоренность была достигнута и к первой годовщине ТРАМа (19 марта 1932 г.) состоялся выпуск 25 актеров, окончивших шестимесячные общеобразовательные актерские курсы [5, с. 58-59].

За два года работы ТРАМ подготовил и включил в свой репертуар 5 пьес на актуально-политические темы, написанные самими трамовцами: «Маньчжурские события» (автор - Сун-Бун-Мо), «Конец капитализма» (СунБун-Мо), «Ленинские дни» (Ван-Сю-Кин), «Новый быт» (Ван-Сю-Кин) и «Сознание» (коллектив авторов) [19, л. 1].

За последующие несколько лет было подготовлено еще ряд новых пьес: «Ван-Фу-Лин» (авторы - Кирюченко и Левин), «Бой начат» (Цай-Ен), «Тудыгомин» (Сяо), «Латинизация» (Ко-Зы-Дю), «Уголь» (Цай-Ен), «Защита Шанхая»
(Тин-Шань), «Чапей» (Цай-Ен), а также старое произведение, прошедшее идеологическую переработку: «Кантонская коммуна» (Ван-Сю-кин) и др. [3, с. 95; 7, с. 23].

В августе 1932 г. китайский ТРАМ участвовал в 1-й Всесоюзной олимпиаде искусства в Москве, где за свою работу и мастерство, «как одни из лучших коллективов, был премирован ВЦСПС поездкой по СССР и получил Красное Знамя от редакции газеты «Советское искусство» «за идейность и мастерство» $[19$, л. 1].

Кроме Москвы, артисты посетили Горький, Ленинград, Харьков, города Донбасса, Баку, Ташкент и Новосибирск, везде они были радушно встречены рабочими и всей общественностью. Однако, когда ТРАМ вернулся 16 декабря 1932 г. во Владивосток, оказалось, что здесь он никому не нужен. Китайских зрителей стало гораздо меньше: многие уехали из-за осложнения отношений между СССР и Китаем.

Китайский ТРАМ оказался в крайне тяжелых условиях из-за отсутствия средств к существованию и нормальных условий работы, в результате чего артистам три месяца не выплачивали жалование. Несмотря на то, что TPAM числился по сметам, как края, так и города его никто не финансировал, за исключением китайского театра, который сам не получал никаких дотаций.

Отсутствие средств к существованию и нормальных условий работы грозило развалом ТРАМа. Для устранения возникших трудноститрамовцами были приняты ряд мер. Сохранив свой «революционный репертуар» в 1933 г., театр дал 48 спектаклей в рабочих клубах Дальзавода, Эгершельда, железнодорожного депо, клубе им. 1 Мая и других предприятий [5, с. 60]. Началась активная борьба с существующими недостатками: за один только 1933 г. около 20 актеров, десятки лет, куривших опиум, перестали курить и играть в азартные игры. Из стен театра были выведены банковка и контрабанда, улучшены бытовые условия [3, с. 95]. Но навести порядок в хозяйственно-финансовой деятельности ТРАМа в 1933 г. не удалось: в театре отсутствовал план работы, учет имущества и материалов, имелись факты нарушения тарифной дисциплины: работник имел ставку, проведенную приказом, 600 руб. - получал 750 руб., другой вместо 400 руб. - получал 600 руб. и т.д. Для наведения порядка в хозяйственно-финансовой деятельности в 1934 г. в ТРАМ был прислан новый бухгалтер, которому удалось ликвидировать существующие недостатки. Для оказания помощи театру в хозяйственной и творческой деятельности, к театру был прикреплен квалифицированный сотрудник [21, л. 62-63].

В 1934 г. старый китайский театр, в котором работало 97 чел., работал бездефицитно, получив 146 тыс. руб. чистой прибыли [22, л. 102]. К достижениям старого китай- 
ского театра можно отнести и четыре новые постановки «Тайпинское восстание», «Чапей», «Красный Шахтер» и «Рычи Китай» [15, л. 37].

Учитывая то, что по существу театр не использовался на все 100\%, 16 июня 1934 г. традиционный китайский театр и театр ТРАМ вновь отправились в поездку сроком на три месяца по крупнейшим городам СССР со своими новыми пьесами «Защита Шанхая», «Чапей», «Ван-ФуЛин» и др. [10].

Репертуар гастрольной поездки, рассчитанной на 4 вечера, по два отделения в каждом, был следующий: Первый вечер: первое действие включало в себя знакомство зрителя с традициями китайского театра (не более 20 мин.), отрывок из пьесы «Обезьяна, кошка и тигр», игры театрального оркестра и танцев; второе действие - отрывок драмы (исторической или бытовой) с элементами акробатики, пьесу «Подарить водку» или «Ошибка в ошибке» и пьесу «Саньчакоу». Второй вечер: первое действие: пьеса «Подарить водку» или «Ошибка в ошибке», пьеса «Мулань» или «Самоубийство Танхуэй»; второе действие - пьеса «Чапей» и пьеса «Тайпинское восстание». Третий вечер: первое действие - пьеса «Подарить водку» или «Ошибка в ошибке» и пьеса «Застава Хунни»; второе действие - отрывки из пьесы «Рикша» и др. Четвёртый вечер - пьеса «Фун-Бо-Тин» $[22$, л. 3233(об)].

Одновременно с развитием китайского театра рабочей молодежи шел процесс его слияния со старым китайским театром. Несмотря на то, что в 1932 г. последний уже поставил 3 пьеса с советской тематикой, принцип его работы до 1934 г. оставался прежним - постановка варьете и шантанов, в нем постановки шли с утра до позднего вечера. Под влиянием китайского ТРАМа с 1934 г. старый театр перестроился на рельсы европейских театров. Туда был специально прикреплен партийный работник, который вместе с сотрудниками Ленинской школой занимался переводом пьес.

Однако достигнуть желаемого слияния театров было нелегко. Бой между двумя театрами, старым, феодальным пропитанным конфуцианской моралью и новым TPАМом - был длительный и жестокий, потребовалась большая и жестокая ломка ряда феодальных традиций и привычек в работе, в быту и психологии.

В 1935 г. ТРАМу удалось привлечь старых китайских актеров к постановке пьесы «Тайпинское восстание», для оказания методической помощи театру были привлечены ученые и литературные круги китайской диаспоры. Для того, чтобы привлечь русского зрителя, трамовцы обратились за помощью в переводе пьес с китайского языка на русский к студентам и сотрудникам Китайской ленинской школы и других китайских учебных заведе- ний $[19$, л. $1 ; 20$, л. 6; 22, л. 14-15].

Несмотря на определенные успехи, деятельность и состояние китайского театра продолжали беспокоить партийные и советские органы. Для улучшения массовой работы театра предполагалось организовать с помощью курсантов Китайской ленинской школы и артистов театра массовую работу вокруг новых постановок, путём проведения бесед, докладов в общежитиях рабочих города (китайских и русских) и др. А для улучшения материально-финансовой базы театра и положения работников предполагалось поставить китайский театр на госбюджет и не сокращать дотации, организовать питание коллектива театра в столовой промыслового союза $[15$, л. 37-40].

В письме директора театра Н.3. Кирюченко от 26 марта 1937 г. на имя секретаря Крайкома ВКП(б) И.М. Варейкиса подробно описывались перемены, которые произошли в деятельности театра По мнению директора, «театр совершенно изменил свое лицо и не только лицо, но и содержание. Из театра типа кафе-шантана, с присущими ему столиками, закусками, семечками в зрительном зале, летающим полотенцем для вытерания пота, с царящей повсюду грязью и крайней некультурности, как в зрительном зале, так и на сцене, и в содержании пьес», где разыгрывались никому не нужные, непонятные трагедии о жизни древних императоров, богов и мудрецов, театр «превратился в культурное учреждение, стал понятен и любим китайскими массами. Изменилось лицо театра, изменились актеры, вырос китайский ТРАМ, изменился и репертуар театра. Мы выбросили все мертвое, ненужное, весь хлам, сохранив все национальные, культурные, и исторические ценности» $[20$, л. 6].

В 1935 г. коллектив ТРАМа активно включился в подготовку празднования 15-летия Приморского комсомола. Праздничные мероприятия включали смотры художественной самодеятельности; выставки молодых художников; выступления молодых литераторов, музыкантов, певцов, а также китайского ТРАМа, предусматривалось, что каждая первичная организация должна продемонстрировать успехи в области политучёбы и внутрикомсомольской работы [16, л. 74].

Интерес к китайскому рабочему театру вновь усилился в 1936 г., когда было принято совместное решение Всесоюзного комитета по делам искусств и Далькрайкома ВКП(б) о выезде театра на гастроли по СССР в мартаоктябре 1936 г. на организацию гастролей планировалось выделить 25 тыс. руб. на оформление спектаклей и 20 тыс. руб. - в качестве аванса отъезжающим артистам театра $[20$, л. 13$]$.

В мае 1937 г. китайскому театру было дано разрешение на новую гастрольную поездку по СССР сроком на 
4-5 месяцев по маршруту Москва - Ленинград - Киев - Харьков - Баку - Тифлис - Свердловск - Новосибирск. Директор ТРАМа Кирюченко считал, что данная гастрольная поездка разрешит многие, если не все, проблемы театра. Гастрольная поездка была очень важна и для дальнейшего существования театра [20, л. 7]. Для гастролей были отобраны 2 пьесы (классическая пьеса «Фун-Бо-Тин» и новая пьеса «Маньчжурские события») и 9 отрывков из разных классических революционных пьес [20, л. 26].

В 1937 г. началась волна массовых репрессий в отношении китайских иммигрантов. За 1937-1938 годах было арестовано 11 тыс. и депортировано ещё 8 тыс. китайцев [6, с. 102-103]. Чем меньше становилось потенциальных зрителей, тем труднее было содержать театр и его трупу. Охладевать к китайскому театру стали и партийные, и советские структуры региона.

Падение интереса к китайскому театру ярко проявилось в сокращение количества спектаклей и зрителей, так в 1937 г. театр дал всего 308 спектаклей, которые посетили 78 тыс. 888 чел. [30, л. 171] зрителей, по сравнению с 1934 г. количество зрителей уменьшилось почти наполовину.
В обстановке усиливавшихся репрессий вся деятельность китайского театра вызывала серьёзные подозрения. В результате к 10 апреля 1938 г. из 51 артиста китайского театра 29 репрессировали. В мае 1938 г. директор Н.3. Кирюченко также был арестован органами НКВД. Решением бюро Приморского обкома ВКП(б) от 9 июня 1938 г. в пятидневный срок вся работа китайского театра была свернута, его здание передано областному управлению НКВД. Так завершился творческий путь китайского ТРАМа, являвшегося своеобразным экспериментом советской власти, попытавшейся соединить традиции европейского и восточного театрального искусства ради политического воспитания китайских трудящихся $[24$, л. 7].

Таким образом, китайские театры, сохранив национальные художественно-выразительные средства театрального искусства, представляли для китайцев, проживающих в России, не только место отдыха и развлечения, но и помогли им сохранить чувство принадлежности к родине. В то же время театры стали одним из важных орудий как для политической агитации среди китайцев советских властей, так и для пропаганды русского и советского искусства.

\section{ЛИТЕРАТУРА}

1. Алепко А.В., Бондарь Г.А. К вопросу о клубах, театрах и печати китайской диаспоры советского Дальнего Востока в 1923 - 1930 гг. // Россия и Китай: история и перспективы сотрудничества: материалы VIII Международной научно-практической конференции (Благовещенск — Хэйхэ — Чанчунь, Шеньян, 21—8 мая 2018 г.). Вып. 8. / отВ. ред. Д.В. Буяров, Д.В. Кузнецов. Благовещенск: Изд-во БГПУ, 2018. С. $219-224$.

2. Анча Д.А., Мизь Н.Г. Китайская диаспора во Владивостоке: страницы истории. Идз. 2-е, допол. Владивосток: Дальнаука, 2015. 310 с.

3. Ващук А.С., Чернолуцкая Е.Н., Королева В.А., Дудченко Г.Б., Герасимова Л.А. Этномиграционные процессы в Приморье в XX веке. Владивосток, 2002.228 с.

4. Граве В.В. Китайцы, корейцы и японцы в Приамурье // Труды командированной по Высочайшему повелению Амурской экспедиции. Вып. ХІ. СПб., 1912. $489 \mathrm{c}$.

5. Кулинич Н.Г. Китайский театр рабочей молодежи на советском Дальнем Востоке (1930-е гг.) // Новый исторический вестник. 2011. № 1(27). С. 57-64.

6. Ларин А.Г. Китайцы в России вчера и сегодня: исторический очерк. М., 2003. 220 с.

7. Левин И. Советский китайский театр // Советский театр. 1935. № 5-6. С. 23.

8. Преснякова Л.В. Традиционный китайский театр на русском Дальнем Востоке и в полосе отчуждения КВЖД в конце XIX — начале XX в. // Вестник ДВО РАН. 2006. № 2. С. 114-122.

9. Соловьев Ф.В. Китайское отходничество на Дальнем Востоке России в эпоху капитализма (1861—1917 гг.). М., 1989. 124 с.

10. Тихоокеанская звезда. 1934. 27 мая.

11. Чжан Юнхэ. 张永和. 张永和聊史说戏. Чжан Юнхэ Ляоши Шуоси. [История и китайская опера, изучаемая Чжан Юнхэ]. Пекин: Изд-во Пекин, 2019. $371 \mathrm{c}$.

12. Чжэн Чуаньинь. 郑传寅. 中国戏曲史. Чжунгуо Сицюй Ши. [История китайского театра]. Пекин: Изд-во высшего образования, 2018. 371 с.

13. Государственный архив Приморского края (ГАПК). Ф.П-1. Оп. 1. Д. 710.

14. ГАПК. Ф.П-З. ОП. 1.Д. 254.

15. ГАПК. Ф.П-З.ОП. 1. Д. 602.

16. ГАПК. Ф.П-67. Оп. 1. Д. 172.

17. Государственный архив Хабаровского края (ГАХК). Ф. П-2. Оп. 1. Д. 45.

18. ГАХК. Ф.П-2. ОП. 1.Д. 95.

19. ГАХК. Ф.П-2. Оп. 11. Д. 167.

20. ГАХК. Ф.П-2. ОП. 11. Д. 188.

21. ГАХК.Ф.П-2. Оп. 11. Д. 189 
22. ГАХК. Ф.П-2. Оп. 11. Д. 193.

23. ГАХК. Ф. П-2. Оп. 11. Д. 241.

24. ГАХК. Ф. П-2. ОП. 11. Д. 243.

25. ГАХК. Ф.П-2. ОП. 11. Д. 404.

26. ГАХК. Ф.П-2. Оп. 11. Д. 96.

27. ГАХК. Ф. П-2. ОП. 9. Д. 75.

28. ГАХК. Ф. П-2.0П. 9. Д. 77.

29. ГАХК. Ф. П-2. Оп.11. Д. 243.

30. ГАХК. Ф.Р-719. 0п. 6. Д. 3.
๑ Чжао Хуэйцин (273004890@qq.сот), Мэн Фаньхун (479884839@qq.com),
Дударенок Светлана Михайловна (dudarenoksv@gmail.com).

Журнал «Современная наука: актуальные проблемы теории и практики»

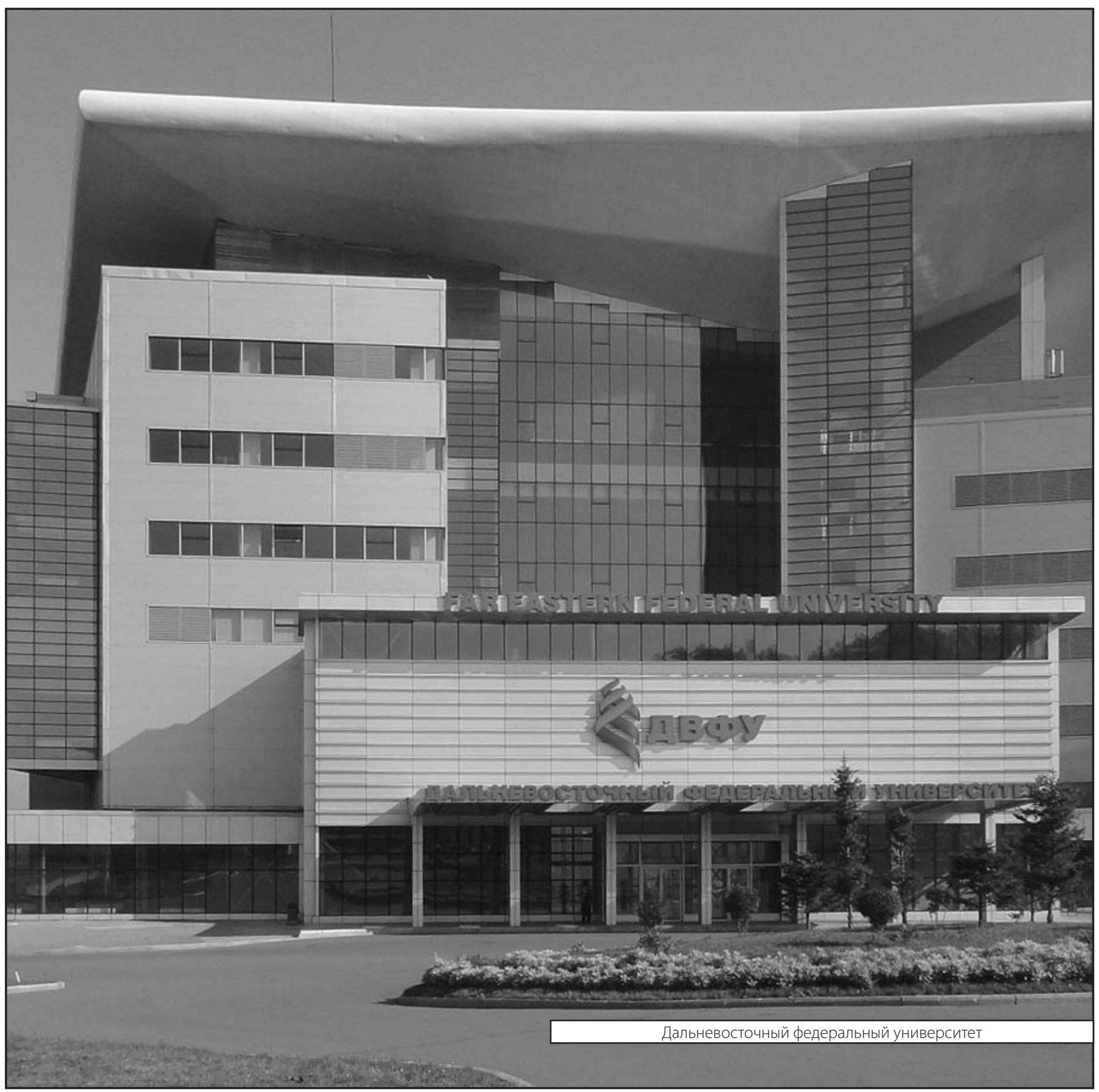

